\title{
The Lord of the Rings. The Tale and the Unfolding Wisdom of Lawyers
}

\begin{abstract}
This essay aims to explore the political and legal philosophical layers of J.R.R. Tolkien's masterpiece. First, it demonstrates the ambivalent feature of power and authority appearing in The Lord of the Rings. The second part gives a reading of Tolkien's philosophical anthropology. Next, it is shown how Tolkien's concept of law can be placed in the framework of a Lockean political theory. Finally, the paper discusses the educational potential of this literary work in the process of moral and legal socialization of the "lawyers-to-be".
\end{abstract}

Keywords: law and literature, Lord of the Rings, legal education

"I have forgotten much that I thought I knew, and learned again much that I had forgotten." 1

\section{The Dark Side of the Power}

The primary concerns of The Lord of the Ring are the nature and the division of power. The plot revolves around the Ruling Ring what Sauron, the Dark Lord, made forged in the fire of Mount Doom in the previous age of the world. Other magic rings were also created and the kings of the Elves, those of the Dwarves, and those of the Men got them from Sauron. These rings acquired their power from the One Ring serving as means for Sauron to subdue the peoples of the Middle-Earth. "One Ring to rule them all, One Ring to find them, One Ring to bring them all and in the darkness bind them."

The history of the One Ring reveals the immense corrupting force of the absolute power. First, it destructed Isildur who obtained it from Sauron defeating him in the last great battle of the previous age when the alliance of the Elves and the Men fought against the Dark Lord's forces. But Isildur could not resist the temptation of power, and therefore he failed to throw the Ring into the Cracks of Mount Doom. Two thousand years later the Ring got to Gollum who killed his cousin to claim it for himself. The Ring gave an unnatural long life to Gollum living nearly six hundred years under its magic. Being exiled from his people and lurking in the depths of the Misty Mountains, Gollum slowly became a pitiful and frightful monster.

However, the Ring left Gollum since it felt the return of the spirit of its Master, and Bilbo, the Hobbit, found it, and he still kept the Ring by himself for sixty years. Although Bilbo was the only one among the "Ring-bearers" who could voluntary renounce the Ring,

* Associate professor, Faculty of Law, Pázmány Péter Catholic University, H-1088 Budapest, Szentkirályi u. 28-30.

E-mail: kopi@jak.ppke.hu

1 Tolkien, J. R. R.: The Lord of the Rings: The Two Towers. New York, 1965 [hereafter: The Two Towers]. 125.

2 Tolkien, J. R. R.: The Lord of the Rings: The Fellowship of the Ring. New York, 1965 [hereafter: The Fellowship of the Ring], vii. 
he needed to this the help of the wizard, Gandalf the Gray. ${ }^{3}$ Then the Ring was given to the noble-minded Frodo whom the White Council assigned the mission of destroying it. It meant that the Ring must have been returned to the Cracks of Doom in Mordor, the realm of Sauron. However, Frodo also failed in the last moment, his moral strength was broken by the Ring, and the success of his mission depended on pure luck.

The absolute power can not serve any "good" aim. Gandalf's words, by which he declines Frodo's offer to take the Ring to himself, are illuminating.

"With that power I should have power too great and terrible. And over me the Ring would gain a power still greater and more deadly.' His eyes flashed and his face was lit as by a fire within. 'Do not tempt me! For I do not wish to become like the Dark Lord himself. Yet the way of the Ring to my heart is by pity, pity for weakness and the desire of strength to do good. Do not tempt me! I dare not take it, not even to keep it safe, unused. The wish to wield it would be too great for my strength."'4

Nevertheless, the absolute power ruins not only the true and the innocent but also the Orcs, the servants of the Dark Lord. They are constantly wrangling, and they solace their fear from the "bigwigs" by cruelties against each other. Several times during his adventurous travel, Frodo can escape only because his pursuers start fight among themselves. ${ }^{5}$

The Dark Lord's fall is also caused by the enchantment of power at the end. Sauron cannot reveal the imminent danger, while he cannot imagine that someone wants to get the Ring just for destroying it. ${ }^{6}$ On the other hand, he can trust neither in his servants and nor in his allies who, if they recognise the power of the Ring, would claim it for themselves. This enlights the self-destructive characteristics of tyrannical power.

Saruman, who has been once the head of the Magicians' Order and of the White Council, betrays the Council and allies with the Dark Lord. He raises a great army in his fortress, Isengard, and with the Lord of Mordor, they take in crossfire the free peoples of Middle-Earth. But Saruman secretely wants the Ring for himself, and Sauron soon recognises the potential rival in him. So Saruman divides and distracts Sauron's attention from the real intention of his enemies.

Sauron sets free Gollum to find and claim the Ring for him. But Gollum is driven by the only desire to retrieve the Ring-his precious-what he had owned for so long time once. He rather undertakes to lead Frodo in Mordor-meanwhile he is constantly looking for the opportunity to seize his precious from Frodo-just for precluding that the Dark Lord lays hands on it. And in the last moment, when Frodo realises that he cannot give up the Ring, then Gollum tears away it from him, and falls with it into the glowing cauldron.

${ }^{3}$ Gandalf could persuade Bilbo to leave the ring to Frodo in fact only by a surprising action of his authority. First he tried to talk Bilbo over, but when the dispute deteriorated, Gandalf, who generally wandered "incognito", revealed his true power, "[...] and he seemed to grow tall and menacing; his shadow filled the little room." The Fellowship of the Ring, 59-60.

4 The Fellowship of the Ring, 95.

5 Tolkien, J. R. R.: The Lord of the Rings: The Return of the King. New York, 1965 [hereafter: The Return of the King], 248-249; see also "The Uruk-Hai" in The Two Towers, 58-79 (esp. 66-69); "The Tower of Cirith Ungol" in The Return of the King, 211-235 (esp. 221-227).

${ }^{6}$ See The Two Towers, 127-128, and also "The Last Debate" in The Return of the King, 181194 (esp. 190-193). 
It is worth stopping, for a moment, at this dramatic scene, because its metaphorically thickening meanings illuminate further characteristics of the contradictory nature of power. The absolute power dwindles away in the tension of the forces aiming to hold it. The moral strength in itself is not enough to curb the concentrated power: it must to level power against power. In fact, this insight is the foundation of the division of power.

But Gollum's fate exemplifies that rational deliberation of the risks of power is not enough for its limitation of absolute power. Gollum can reach to the Mount Doom only because first Bilbo, then Aragorn-the King of the Men-and Gandalf, and at last Frodo spared his life, although his corruption and wickedness has given several causes for his destruction. ${ }^{7}$

Saving Gollum's life is not an irrational deed. On the one hand, Gandalf believes that Gollum can be healed out from his wickedness, even if this has not much of a chance to happen. On the other hand, Gandalf, just because he knows the self-destructing character of the absolute power, thinks that Gollum is involuntary capable to help them: "Let us remember that a traitor may betray himself and do good that he does not intend." reasons have been justified to a certain degree during the dangerous mission. At the last stay on the road to Mordor Gollum lets slip a chance to seize the Ring from Frodo, because he suddenly feels sorry for Frodo who has tried to handle him decently in the course of their forcedly shared travel. Gollum has seemingly started to cure out of his wickedness, at least for a while, under the influence of Frodo's goodness. ${ }^{9}$ And in the last dramatic moment, in the Crack of Mount Doom, Gollum falls with his madly desired precious in the seething kettle.

The absolute power is destructing and self-destructing-this is the dark side of power. The tyrannical power is never capable to create: it can only imitate and distort the existing creatures. ${ }^{10}$ The existence of this dark power in the word notwithstanding contributes to the rich emanation of the creative forces. With the perishing of the One Ring, the other rings lose their magic forces, too, and all of those great works which have been built by their help dwindle to nothing.

\section{The Ages of the World and the Human Nature}

The Third Age of the World ends by the War of the Ring. Therefore, only rare references can be found to the events of the previous epochs in The Lord of the Rings. ${ }^{11}$ The history of these ages can be learned from The Silmarillion.

The First Age of the World begins with the creation of the Earth-Arda-and ends with the expelling of Melkor-or Gorgoth as the Elves calls him-, the spirit of envy, revolt and evil, into to the Timeless Space. In this period takes form the face of the Earth in the midst of the fights of the Valars-the creating and protecting spirits of the Earth-against Melkor. Then the children of Ilúvatar, Father of All, awake: first the Elves, later the Men.

7 Cf. The Fellowship of the Ring, 92-93.

8 The Return of the King, 108.

9 See The Two Towers, 411.

10 Neither the Orcs were created by Sauron: their ancestors had been Elves who were captured by the enemies, and their nature distorted by torture. See Tolkien, J. R. R.: The Silmarillion (ed. Tolkien, C.). London, 1999 [hereafter: The Silmarillion], 47.

11 See also: "Appendix B, The Tale of Years" in The Return of the King, 452-472. 
The Elves resemble Men in their physical appearance, but they are alike to the Valars in their nature, since they are immortals: "For the Elves die not till the world dies, unless they are slain or waste in grief (and to both these seeming deaths they are subject); neither does age subdue their strength, unless one grow weary of ten thousand centuries; and dying they are gathered to the halls of Mandos in Valinor [the isle of the Valar], whence they may in time return." 12 The Elves are high-minded and skilled in many trades and arts-especially in singing and poetry-what they have learned directly from the Valars. The Elves' wisdom increases by the time, but so does their sorrow, because they witness the changes of Arda, and see how the great works of the earlier times fall, and how the world "becomes colourless".

The Men awake after the Elves. They have less physical strength and they are more vulnerable than the Elves, from whom they learnt most of their knowledge. But Ilúvatar has prepared a peculiar gift for them: the Men are free-" "they should have a virtue to shape their life, amid the powers and chances of the world" [...]:

"It is one with this gift of freedom that the children of Men dwell only a short space in the world alive, and are not bound to it, and depart soon whither the Elves know not. [...] [T] he sons of Men die indeed, and leave the world; wherefore they are called the Guests, or the Strangers. Death is their fate, the gift of Ilúvatar, which as Time wears even the Powers shall envy. But Melkor has cast his shadow upon it, and confounded it with darkness, and brought forth evil out of good, and fear out of hope."13

The Dwarves also appear in the Old Times, however, they are not Ilúvatar's offspring, but the creations of a Vala. They are physically smaller than the Elves and the Men, but more stubborn, and they endure suffering more then any other people. Since their fathers were created in the time when Melkor's power shadows the world, the Dwarves have lived underground. Because of that, they are masters of mining and the art of metallurgy. The Dwarves are generally closed, so they do not care so much for the Elves and the Men, they have made closer friendship only with Elf smiths. The Dwarves are equally steady in friendship and hatred that is why Melkor's magic does not have much effect on them, and their primary habit is the avid love of treasures. ${ }^{14}$

The Ents, the shepherds of trees, were also born in the First Age. Yavanna, the creator Vala of the flowers and trees, gave life to these powerful beings, because she had seen that the fields and forests were threatened not only by Melkor's wrongdoings, ${ }^{15}$ but also by the Elves, the Men and the Dwarves. ${ }^{16}$ The Ents' task is to protect the forests and to punish those who absent-mindedly or unnecessarily cut down trees. There cannot be found too much about the Ents in the chronicles of the Old Times and those of the Second Age, so they

12 The Silmarillion, 36.

13 Ibid.

14 Ibid; see also The Return of the King, 437-451.

15 The evil power threatens not only the speaking beings-the Elves, the Men and the Dwarvesbut all of the livings. Wherever it gets a foothold, it turns the landscape into dreary desert. The description of Mordor for example can at best evoke in the readers' mind the picture of an industrial wasteland, or a wreck dumping ground. Cf. The Two Towers, 302.

16 The Silmarillion, 40-42. 
appear rather unexpectedly at the end of the Third Age, in the War of the Ring: they destroy a great part of Saruman's troops, and they imprison the magician in his tower at Orthanc. ${ }^{17}$

The First Age of the Word is elapsing by the struggle of the Valars and the Elves against Melkor. The Men do not play a significant role in this epoch, although, by the end of the Old Times, several heroes emerge among them who have fought on the side of the Elves against Gorgoth. Yet these heroes are also tangled up in the net of Melkor's lies-he can raise discord even between the Elves-, so most of the Men become servant of the evil. Then the alliance of the Valas and the Elves defeats Gorgoth in the War of Wrath. Most of the Elves leave Middle-Earth after this, and move to the island of Tol Eressa, from where they can sail to Valinor.

The Second Age begins with the rise of Númenor, the realm of the Men. But the Valars have not destroyed all the evil's power by expelling Melkor: a number of servants of the evil escape, among them Sauron who will collect the forces of evil later. Sauron feigned repentance for a long time, while he made the Rings of the Power with the help of the Elf smiths. Although the Kings of Elves realised that Sauron had betrayed them, so they hid their rings, the other rings given to the Dwarves and the Men fulfilled the power of the One Ring: the Kings of Men became the servants of the One Ring, the Ringwraiths, and the Dwarves were ruined by their rings from which two perished and the other five were reclaimed by Sauron in the Third Age.

Suaron could not win Númenor with force, however, so he deployed a stratagem. He went to Númenor as a hostage, but he soon poisoned the mind of the King. Sauron persuaded him to turn against the Valars claiming the immortality for the Men with arms. The Valars got Númenor sunk in the depth of the sea, and they hid Valinor from the mortals: the face of the World changed again.

Only a few men, who remained loyal to the Valars, survived the drowning of Númenor: Elendil and his two sons, Isildur and Anárion. The tide, which destroyed Númenor, cast them into the Middle-Earth where they founded two kingdoms, Gondor and Arnor. Sauron's spirit reincarnated in Mordor, and he promptly attacked the two kingdoms. The Elves made alliance with the Men, and they defeated Sauron in the last battle of the Second Age whereupon Isildur took hand on the One Ring.

At the beginning of the Third Age, Isildur was killed and the One Ring disappeared. The magicians-the Istars-, appeared around the end of the first millennium of the Second Age; they had been sent by the Valars to aid the Men and the Elves against Sauron, "and to unite all those who had the will to resist him; but they were forbidden to match his power with power, or to seek to dominate Elves or Men by force or fear." 18 The two most important members of the Order of Magicians were Saruman and Gandalf, the "Gray Pilgrim". Saruman had already studied the skills of forging magic rings for long time, because he wanted to defeat Sauron with this knowledge. Although he was more and more involved in dark practices, and, first, he had started to admire Sauron, later to envy him, and, at the end, he betrayed the White Council for laying a hand on the One Ring.

The story of The Lord of the Rings is set in the Third Age of the World, and it begins when Gandalf discovers that the Ring is in Bilbo's hand. The alliance of the Elves, the Men

17 Saruman's undoing has been caused by he made cut the forests around Eisengard for getting wood necessary to stir fire for the black magic, enraging the Ents with this. See The Two Towers, $186-231$.

18 See "The Grey Pilgrim", The Return of the King, 455. 
and the Ents undo the power of Saruman and Sauron at the end of the Ring's War. The ring is perished in the fire of Mount Doom and Sauron's spirit is left for ever. Aragorn, Isildur's heir, takes Gondor's throne, and the rest of the Elves leave Middle-Earth, with the Ring bearers-Bilbo and Frodo-, they sail to Valinor. With this begins the Fourth Age of the World, the Age of the Men.

What can we learn from this story about the world and the nature of men? First of all, that the world is declining. The forces forming the world have been losing their strength for Ages: Sauron was only a servant of Melkor, and, as first the Valars had left it, at the dawn of the Men's rule, the Elves also leave the world. The Men could become the master of the world only after the superhuman forces are already tamed it. The struggle of the creating and destroying forces wounds the face of Arda again and again while with their lessening strength, extinguishing each other, the world is "loosing its colour".

But the Men are free, so it's only their turn when their times sets in, whether they save the beauty of Arda, they renew it, or they spoil her and make her infertile fulfilling her destiny. So, the Men are responsible for the fate of Earth.

The primary problem of the human nature is the price of freedom: mortality. Originally, death was a gift-the spirit of the man can leave the circles of the World ${ }^{19}$-but Melkor had changed it into a curse, into the fear from death that makes the Men defenceless against the power of violence and that of dread. This caused the fall of the mankind and that of the realm of Númenor: while the Númenorians' power and richness was increased, "but their years lessened as their fear of death grew, and their joy departed." ${ }^{20}$ They more and more desired immortality, and it caused the fall of Númenor at the end.

Aragorn's life exemplified the Men's original, uncorrupted relation to the death. He was the last breed of the Kings of Númenor, who had been given three times longer life than other common mortals. He fought as a hero against Sauron. He occupied the throne of Gondor at the end of the Ring's War, and married Arwen-his love since his youth-, the daughter of Elrond, who was the King of the Elves. Then Arwen waived the immortality for the sake of her love, and she chose the fate of the Men. Nevertheless, Aragorn had not only the privilege of the long life, but, as all his ancestors, also of choosing the time of his exit. So, when he felt his decline arriving, he said farewell to Arwen, and offered her to choose between the fate of the Men and immortality once again.

"'Nay, dear lord,' she said, 'that choice is long over. There is now no ship that would bear me hence, and I must indeed abide the Doom of Men, whether I will or I nill: the loss and the silence. But I say to you, King of the Númenoreans, not till now have I understood the tale of your people and their fall. As wicked fools I scorned them, but I pity them at last. For if this is indeed, as the Eldar say, the gift of the One to Men, it is bitter to receive.'

'So it seems,' he said, 'But let us not be overthrown at the final test, who of old renounced the Shadow and the Ring. In sorrow we must go, but not in despair. Behold! we are not bound for ever to the circles of the world, and beyond them is more than memory, Farewell!'"21

19 Cf. The Silmarillion, 316.

20 The Return of the King, 392.

21 The Return of the King, 427-428. 
Well, the Man is free: even if he is exposed to the fear of death, yet he can overcome of it, and he can assure the peace of his conscience with virtuous deeds. Nevertheless, the virtues could be many kinds, and they are changing themselves by the ages of the word. The story of the Lord of the Rings ends at the dawn of the Men's Age, in the door of freedom, and we would not know to what direction will be taken the Mankind's fate. The Work calls the Reader by this, and encourages him to continue the tale, to think over and to make a decision about the Mankind's fortune. Did we really stop the decay of the Word? Several handholds are given to the Reader by the Work for the quest of the answer to this question-although the answer itself depends exclusively on the Reader-, because the various peoples and heroes playing roles in the story are exemplifying different virtues and characteristics that can lead the Mankind's fate in diverse directions.

The Elves appearing in the Ring's War embody the refined aesthetic values, harmony and beauty. ${ }^{22}$ They are strange, dreamlike beings, whose bodily existence is airy, and their wisdom turns into silence and riddles. ${ }^{23}$ But their wisdom has been matured slowly. In fact, the Third Age Elves are inheritors of a heroic value system: their ancestors lived in a constant war against Melkor, and their exaggerated pride plunged them into fraternal war in the previous word age. ${ }^{24}$ It seems that their beauty is an essence distilled from heroism mellowed in their wisdom and grief.

The beauty and perfection of the "Firstborns" is unattainable for the Men. Yet, the fading human memory still keeps the reminiscences of the Elves' love for Arda and their noble-mindedness in the everlasting craving for the Lost Paradise, for beauty, peace, and harmony. Among the Men, Aragorn embodies the most excellence by the Elves' virtues-the heroic desperation against the evil and the refined aesthetic sense-, although his eminence is "superhuman", like that of the Greek mythological half-gods. Nevertheless the source of his wisdom cannot be found in the Elves' thinking, but in the teachings of Gandalf, the Grey Pilgrim.

As we have already seen, the two most prominent features of the Magicians' Order are Gandalf and Saruman. Their prominence and power burst from the same stem: both of them lean upon the force of the rational. However, they know well the mysteries of the nature and of the human mind, as well as they are masters of the art of persuasion. Although, while Saruman symbolises the technical knowledge uncontrolled by the moral virtues, ${ }^{25}$ then Gandalf represents the wisdom guided by the moral virtues.

The technical knowledge-the capacity for producing artefacts-is neutral in itself, neither good, nor bad. But the possession of this knowledge means a temptation for its bearer to enter in competition with nature. ${ }^{26}$ In fact, the arrogance and the desire of power defeated even Saruman at the end.

22 The Hobbits called the Elves as "Fair Folk". Cf. The Fellowship of the Ring, 119.

23 "Elves seldom give unguarded advice, for advice is a dangerous gift, even from the wise to the wise, and all courses may run ill." The Fellowship of the Ring, 123.

24 The Silmarillion, 68-107.

25 Saruman in Elvish was called Curunír, Man of Skill.

${ }_{26}$ While Saruman's practices destroy nature (see note 15 and The Return of the King, 354), Gandalf wins with the force of nature: this is what symbolises the alliance of Gandalf and the Ents. 
What are those virtues which give form and measure to Gandalf's wisdom, and examples and teachings for Aragorn? These are generosity, compassion, and humility. ${ }^{27}$ All these appear in a concentrated form in Aragorn's apotheosis, in the scene of his crowning:

"Then to the wonder of many Aragorn did not put the crown upon his head, but gave it back to Faramir, and said: 'By the labour and valour of many I have come into my inheritance. In token of this I would have the Ring-bearer bring the crown to me, and let Mithrandir set it upon my head, if he will; for he has been the mover of all that has been accomplished, and this is his victory." $" 28$

While the Elves exemplify an ideal value system unattainable for the men, then the description of the Dwarves can even be read as a critique of the modernity. The Dwarves are not evil by nature, and they are not so refined as the Elves, ${ }^{29}$ but they bear many virtues: they are determined and steadfast both in friendship and hatred, they are longing for freedom, ${ }^{30}$ and they are skilled in many kind of craftsmanship. However, their primary weakness is the selfishness-they do not care for nature or for the worries of other peoples, indeed, they have difficulties to get on with each other. ${ }^{31}$ To these failings the craving for treasure has been added by the curse of Melkor and Sauron. ${ }^{32}$ That being said, we can easily recognise the figure of the honourable, workaholic citizens of the modern industrial state in the Dwarves' character who push the world irresistibly, day by day, with their brave efforts to an ecological cataclysm. ${ }^{33}$

Interestingly, at the dawn of the Men's Age, the human-sized "civil" virtues are embodied neither by the Elves or the Dwarves, nor by those heroes like Gandalf or Aragorn, but by the Hobbits. ${ }^{34}$ The Hobbits, about whom we have not talk much yet, ${ }^{35}$ albeit Bilbo and Frodo-the two ring-bearers-and Samwise Gamgee-who is a real folk hero like Sancho Panza-are Gandalf's and Aragorn's companions in the story of The Lord of the Rings. We do not know much about the origin of the Hobbits: the chronicle of the first two ages of world does not mention them, they appear only at the fall of the Third Age. The land of the

27 We do not mention here the courage and the self-denial, because these virtues flow from different sources in the case of Gandalf and that of Aragorn. For Aragorn, these are parts of his "family heritage" and consequences of the Elf values. But for Gandalf, these are acquired virtues which he due to gain through a quasi initiation rite: he has to fight with a Balrog-an Old-Age daemon-, and to descend into the "hell" for returning as White Gandalf who can break the power of Saruman and help the Fellowship overcoming Sauron.

28 The Return of the King, 296.

${ }^{29}$ It is characteristic that while the Elves made jewels then the Dwarves forged weapons and tools. Cf. The Return of the King, 435.

${ }^{30} \mathrm{Cf}$. The Return of the King, 442.

31 See The Return of the King, 445-447.

32 Cf. The Return of the King, 442.

33 Just like the Dwarves who had delved too deep under the Misty Mountains arousing such forces which destroyed them at the end. Cf. The Return of the King, 434.

34 A big hit of the film version (The Lord of the Rings. Trilogy. Directed by Peter Jackson, New Line Cinema, 2001-2003) is that while every other character of the story wear the clothes and arms of the flourishing age of chivalry, then the Hobbits' cloths were of the 17-18 century "civic" fashionexcept that they do not were shoes, because, according to the book, they walk on barefoot, since their feet have tough leathery soles and are clad in a thick curling hair. Cf. The Fellowship of the Ring, 2.

35 See "Concerning Hobbits" in The Fellowship of the Ring, 1-21. 
Hobbits is the Shire, the North-West angle of Middle Earth neighbouring the Grey Havens' land from which the Elves have shipped to Tol Eressa and to Valinor. In their bodily appearance the Hobbits are similar to the Dwarves, just more fragile-we would recon them children according to the human measure-that is why the Orcs call them "Halflings". ${ }^{36}$

The Hobbits are peaceful creatures, and heroic deeds of them had not been noted in the earlier times-that is why Sauron did not notice them at all-, though they can stand their ground if they are strained. They passionately love their land what they cultivate assiduously and diligently, and they do not leave their country's boundaries voluntary, that is why they regard Bilbo and Frodo, who have undertaken adventurous journeys, as a bit fool. However, the Hobbits' industriousness does not couple with selfishness as in the case of the Dwarvesthey are constantly make festivities and give presents for each other-, and their vice is not craving for treasures, but for a good meal and pipe weed.

The most important virtue of the Hobbits, is the capacity for self-government: they themselves elect the leader of the Shire-the Thain-and the citizens of the villages elect Mayor for a certain period. ${ }^{37}$ So, the Hobbits do not need divine kings for keeping order and peace. And when Saruman has escaped, outwitting the Ents, from Isengard to the Shire to resume his dark practices, the Hobbits take their fate in their hands and expel the fallen magician and his servants from the Shire. ${ }^{38}$

The Hobbits try to live in peace not only with their neighbours but also with nature: after expelling Saruman, the first task of Samwise Gamgee is to plant seedlings in the place of the demolished trees. ${ }^{39}$

Besides Frodo, Bilbo and Sam transmit the virtues of Gandalf to the Hobbits as Aragorn to the Men. As Gandalf says when he leaves his friends:

"You must settle its [the Shire's] affairs yourselves; that is what you have been trained for. Do you not yet understand? My time is over: it is no longer my task to set things to rights, nor to help folk to do so. And as for you, my dear friends, you will need no help. You are grown up now. Grown indeed very high; among the great you are, and I have no longer any fear at all for any of you" 40

36 The smallness is symbolic, of course, and it can be unstitched a lot of layers of its meaning from the book, or from its context that means naturally nothing but the Reader's (now the present author's) background knowledge and associations: first of all, the smallness of the Hobbits enlarges their heroism; "we are dwarves, but we are standing on giants' shoulders"-as the modern men should think on the classics' works that laid the foundations of our civilizations; in the Chinese writing the same sign stands for the "wise", the "fool" and the "childe"; The Small Is Beautiful-albeit Tolkien could not read Ernest F. Schumacher's famous writing about a humanist economy, published two decades after appearance The Lord of the Rings, but the descriptions of the Hobbits' life easily can be read as illustrations of these essays.

37 See "Of the Ordering of the Shire" in The Fellowship of the Ring, 12-14.

38 See "The Scouring of the Shire" in The Return of the King, 334-364.

39 See The Return of the King, 367.

40 The Return of the King, 332. 


\section{Natural Law and the Nature of Law}

One can read about law just on a few pages, rather sporadic notes, in The Lord of the Rings. Furthermore, law plays an important role only in a couple of scenes. Although these fragmented references organically and coherently fit in the wider political philosophical frame of the work, we can even learn much about the nature of law from them.

First, law has already existed in the Old Times and the Third Age, ${ }^{41}$ in the period that can be seen as the "state of nature" from the point of view the mankind. ${ }^{42}$ In Aragorn's story, it is mentioned, for example, that the laws of Kingdom of Gondor regulated the process of the choice of the King. ${ }^{43}$ Moreover, one can also find three eloquent episodes in the story of the Ring's War.

In one of them, Aragorn, with his fellows, is chasing a group of Orcs entering the land of Rohan. Here, Éomer, the young Chief Marshal of Riddemark, leading a troop of mounted men, holds them up. Aragorn reveals his identity then and asks him to help or let them continue the pursuit. ${ }^{44}$ Éomer is still reluctant, because he cannot let strangers wandering throughout the land of Rohan for their own good, unless the King gives his permission.

"'How shall a man judge what to do in such times?'

'As he ever has judged,' said Aragorn. 'Good and ill have not changed since yesteryear; nor are they one thing among Elves and Dwarves and another among Men. It is a man's part to discern them, as much in the Golden Wood as in his own house." 45

Éomer decides to let Aragorn on his way, and he even gives them two horses, but he asks Aragorn to visit the King of Rohirs, Théoden, after the chasing, what Aragorn promises, and he fulfills his promise later in fact.

Faramir, son of Denethor, the Steward of the realm of Gondor, gets in a similar situation like Éomer. Denethor learns of the mission of the Ring bearer, and he orders Faramir to arrest the Hobbits and to bring them to him. Faramir, although, when he meets Frodo and understands the aim of the mission-the plan of the destruction of the Ring-, sets Frodo and his fellows free defying his father's command (and the temptation of the Ring). ${ }^{46}$

In the third scene, Beregond, soldier of Gondor, Faramir's devoted man, saves the life of Faramir whom his father, in his bloody furry, wants to burn with himself in the House of

41 The Silmarillion, 310, 314.

42 I use the concept of the "state of nature" here somewhat altering from that of the traditional contractualism, because the "state of nature" happens not by some kind of contract-albeit we can trace the tracks of contract in the story of Aragorn's accession to the throne-, but by the symbolic action of bringing under control the absolute power, that is by the destruction of the Ring and Sauron's power with it. By the way, the concept that the transition from the "state of nature" into the civic state happens not by contracting, but by mastering the absolute power (of which the idea of the contract is only a symbolic expression), is according with the concept of such political thinkers as Guglielmo Ferrero or István Bibó. So the civic state is the subjection of power to the laws, the state of organised peace. On the other hand, the main characteristic of the state of nature is that the law is always threatened by the invasion of absolute power. In my opinion, the picture unfolding from The Lord of the Ring can mostly be related to the Lockean concept of the "state of nature".

43 See "Gondor and the Heirs of Anárion" in The Return of the King, 402-405.

44 See The Two Towers, 32.

45 The Two Towers, 38.

46 See "The Frobidden Pool" in The Two Towers, 361-375. 
Dead. Thus Beregond impedes the execution of this mad order with arm breaching the rule of the Ancient Law that there should be no living in the House of Dead. ${ }^{47}$

And, of course, we should not forget the Hobbits, as "[...] they attributed to the king of old all their essential laws; and usually they kept the laws of free will, because they were The Rules (as they said), both ancient and just." 48 We can also learn that Bag End has been left by Bilbo to Frodo in a properly formed will ${ }^{49}$-for the most earnest pity of the legal heirs, Otho Sackwille-Baggins and his wife, Lobelia.

These details refer to the fact that there is an existing law-the natural law-in the state of nature, although its foundations are not in the power, but in justice and virtues or-as in the Hobbits" "civic" everyday-in usage. Indeed the uncertainty of the state of nature arises from the fact that the absolute power, symbolised by the tyrannous power of Sauron and the One Ring, always threatens the sound functioning of law. For, in the state of nature, the true foundation of the law is not the power relying on force and fear but, on the one hand, the authority flowing from the personal excellency and charisma, and the art of persuasion, the rhetoric, on the other hand.

At certain occasions both Gandalf and Aragorn reveal, respectively, their true personality letting overflow their personal charisma: for example, when Gandalf persuades Bilbo to pass the Ring to Frodo, ${ }^{50}$ when he exposes the intrigues of Saruman to Théoden, ${ }^{51}$ or when Aragorn meets Éomer. The power of their personal influence does not stem from violence or fear, but from the excellence of their personality. This forcelessness belongs to the very core of his mission in the case of Gandalf, while it is granted to Aragorn by his fate-since he is nothing but a hiding heir, a "strider", in the time of the Ring's War.

Although Gandalf and Aragorn use their personal authority only as a last resort, they usually try to persuade their friends or enemies by their arguments. They never ask or order anything without a reason. So the primary device for realising rights and duties is persuasion, the so-called "constitutive rhetoric". 52

The substance of the constitutive rhetoric is very well enlightened in a scene of the Lord of the Rings, in which Gandalf's constitutive rhetoric confronts Saruman's "destructive rhetoric". Following the defeat of Saruman's army by the Rohirs and their allies, he locks himself in Isengard surrounded by the Ents. Then Gandalf, accompanying by his fellowsThéoden, Aragorn and Éomer-rides to the tower of the fortress to try to persuade him to give up his dark conspiracies and to join the Alliance. Though Saruman, a master of the words (and Gandalf has in advance warned his companions of the bewitching power of Saruman's voice), speaking from above the tower's balcony, tries to address them one by one-first Théoden, then Éomer and Gandalf-and to take them on his own part by flattery or threats, outwitting them against each other. First it seems that he succeeds, but as the

47 See "The Pyre of Denethor" in The Return of the King, 141-150.

48 The Fellowship of the Ring, 12.

49 Cf. The Fellowship of the Ring, 51.

50 See note 3.

51 See The Two Towers, 136-141.

52 I have borrowed the term of "constitutive rhetoric" from James Boyd White who sees in this the distinct form of persuasion aiming to re-establish the community of the disputing parties reinterpreting their own respective place in the community forming the face of the community itself by this way at the same time. In a wider sense the concept of "constitutive rhetoric" embodies all linguistic activities contributing to the maintenance of the human community and culture. Cf. White, J. B.: Heracles' Bow. Essays on the Rhetoric and Poetics of the Law. Madison (WI), 1985. 37-39. 
conversation is going ahead, more and more of Saruman's real intention gets cleared before his audience. At the end of the scene Gandalf gives a last chance to Saruman for leaving freely and repairing his faults, but he answers Saruman's high-handed rejection by revealing his true power: he shows Saruman that he already is not "Gandalf the Grey" but "Gandalf the White" who has been returned from death, and he breaks Saruman's magic staff with the force of his mere thought. ${ }^{53}$ When he is questioned by a fellow why he has tried to negotiate with Saruman at all, he replies:

"But I had reasons for trying; some merciful and some less so. First Saruman was shown that the power of his voice was waning. He cannot be both tyrant and counsellor. When the plot is ripe it remains no longer secret. Yet he fell into the trap, and tried to deal with his victims piece-meal, while others listened. Then I gave him a last choice and a fair one: to renounce both Mordor and his private schemes, and make amends by helping us in our need. He knows our need, none better. Great service he could have rendered. But he has chosen to withhold it, and keep the power of Orthanc. He will not serve, only command. He lives now in terror of the shadow of Mordor, and yet he still dreams of riding the storm. Unhappy fool!" 54

When the world steps out of the state of nature not the nature of law but the essence of power changes: the arbitrary, tyrannous power having an end in itself is replaced by the lawful power, and, for the law's foundations are justice and virtue, the lawful power means the morally justified power. The essence of the civic state is thus the rule of law. That is why the pre-existence of the (natural) law bears at least equal importance with that of the act of bringing under control the unlimited absolute power (by destructing Sauron and the Ring) for reaching the civic state.

This can be seen when Aragorn carefully followed the old laws and traditions in the process of accessing the throne: he visited Minas Tirith, the town of Gondor's King, only incognito during its siege; he did not hold up neither the title of the Governor of Minas Tirith, nor that of the Steward of Gondor ${ }^{55}$-although it would be quite natural for everyone in the given situation; and, after the last victorious battle, he entered Minas Tirith only with the permission of the city's Governor and with the consent of the people. ${ }^{56}$ The first task of the King was the jurisdiction after his inauguration: he granted the defeated peoples pardon and delivered an equitable judgement in Beregond's case. ${ }^{57}$

\section{Three Questions}

Next I shall inquire three interrelated questions. First, whether it is worth for lawyers to read literature at all? Is it not enough for practising lawyers to read legal materials and treatises, or, for legal philosophers to read political or legal philosophical works?

The second question is directly bounded to the previous, and it is preconditioned by the positive answer the first. That is, even if we suppose that the literary readings are not without any good for the lawyers yet we can pose the question whether it is worth reading

53 See "The Voice of Saruman" in The Two Towers, 219-234.

54 The Two Towers, 230-231.

55 See The Return of the King, 157.

56 The Return of the King, 293-297.

57 See The Return of the King, 297-298. 
that kind of works like The Lord of the Rings? At last we can still ask why should we read particularly just The Lord of the Rings?

As for the first question it is enough, now and here, to refer to Ian Ward and James Seaton concerning the advantages and disadvantages of applying literature in legal education. ${ }^{58}$

In answering the second question-whether it is worth reading the kind of works like The Lord of the Rings-first we should identify the work's literary genre. Behind this phrasing of the question stands, of course, the implicit assumption that the different literary genres have different importance for the legal mind. We have to add to this the thought already advanced in the title of the present essay, that is-against any opposing rumour-, nobody is born to be a lawyer. Which means that one's decision to choose law as a profession, and to hold herself to this decision subsequently in her later period of life, this is the outcome of a long socialising process developing special motives-striving for justice or wealth, social reputation etc.-and capacities-such as empathy or eloquence-in the personality. So the question of the literary genre can be precise in a way that who-if anyone-should read the kind of works like The Lord of the Rings? Is it valuable for the "done" or for the "would be" lawyers?

Three genres are at hand by the classification of The Lord of the Rings: the tale, the myth and the novel. It is worth recalling the thoughts of Bruno Bettelheim, as a starting point, who compared tale and myth and offered interesting standpoints for the following analysis. $^{59}$

Fist of all, the tale is optimist: it teaches the children that albeit the life keeps in reserve a lot of trials for them, it is always worth fighting, and they can be happy here, in this worldly, everyday life. The tale is related to our ordinary word, and it deals with even the most unexpected events in a natural, unaffected voice. This effect is increased by the fact that the protagonists of the tale are nameless-the "youngest son"-or bear such names"Johnny and July"-that can be seen as collective nouns.

Contrary to tale, myth tells the extraordinary stories of superhuman heroes. Here the protagonists are individual, particular persons-not the "youngest prince" but Theseus or Oedipus-whose stories rather show us what can happen if we do not control certain instinctive impulses-such as vengefulness, jealousy or the marrying of one of our parents -, what tragic consequences will flow from our unchecked behaviour.

When comparing tale and myth to a novel, it can be seen that the novel's main characteristics, and especially the modern novel's one, lies in its complexity. The personality, intentions and actions of the characters are contradictory, and they affect each other in a complex way, and they can change and transform with the move of the plot. That is why the "lesson" of the novel is never unambiguous, therefore it constantly forces the reader to confront with and to recognise the profound uncertainty of the human condition and the sometimes hardly foreseeable consequences of the individual actions.

58 See Ward, I.: “The Educative Ambition of Law and Literature”. Legal Studies, 13 (1993), 323-333; "From Literature to Ethics: The Strategies and Ambitions of Law and Literature". Oxford Journal of Legal Studies, 14 (1994), 389-400; Seaton, J.: "Law and Literature: Works, Criticism and Theory". Yale Journal of Law and Humanities, 11 (1999), 479-507.

59 See Bettelheim, B.: "Fairy Tale versus Myth". In: Bettelheim, B.: The Uses of Enchantment: The Meaning and Importance of Fairy Tales. New York, 1989 [1976], 35-40. 
While the tale as a literary genre is important in the psychic development and the shaping of the child's personality, the myth offers a transition from the tale to the adult literature requiring more mature thinking, so it is a characteristic reading of adolescence and of early adulthood. These points and conclusions are in accordance with the outcomes of the researches which have taken place in the field of "law and literature" concerning the relationships between the literary genres and the process of legal socialization. ${ }^{60}$

Though it is not easy to identify the literary genre of The Lord of the Rings taking in account the above described viewpoints, because the characteristics of all the three genresthe tale, the myth and the novel-can be found in the work. The Lord of the Rings tells us about the extraordinary events of an invented world in common parlance, and the story has a "happy end" within its own frames, so far the work is tale-like anyway. On the one hand, some characters are sketchily portrayed, they rather represent only "archetypes"-e.g. Gimli or Legolas. On the other hand, the protagonists are individuals and superhumans for a certain degree-mainly the character of Gandalf and Aragorn-, not to mention that the plot itself follows clichés of Old English and Celtic mythology. The work recreates this mythological world, so far it is close to the genre of myth.

Although we can discover the characteristics of the novel in The Lord of the Rings, since the story's fictive social background is very elaborated-the author discloses geographical, ethnographic and linguistic descriptions in the Appendix in one and a half hundred pages length-and the "human sized" characters'-of Bilbo's, Frodo's and of Gollum's, not at last-personality is indeed dynamic, and it illuminates their controversial inducements. Furthermore the novel reveals-hopefully as I illuminated it in the previous part of this essay-the dialectic nature of power and authority. It is not by chance that Umberto Eco classified the work into a special genre of the historical novel, the romance, in which "the past [appears] as scenery, pretext, fairy-tale construction, to allow the imagination to rove freely." 61

If we accept Eco's stand-point then we can regard The Lord of the Rings as a kind of "modern myth" 62 by which readers can be localised within the circles of adolescents and young adults. So we can offer the book for the "lawyers-to-be" (and their teachers) as a reading which dramatises the contradictory nature of power, and the relationship of law and justice with an extraordinary force.

Finally, closing our inquiries, let us pose the third question what we can precise taking in account the arguments above: why should we chose just The Lord of the Rings to recommend to the "lawyers-to-be" from the other modern myths concerning the nature of power and law, to which belong such excellent works as Orwell's 1984 or Huxley's Brand New World? We may mention first the optimism of the work that is needed by all of us, not only by the "lawyers-to-be", at the dawn of the 21 st century.

As for the aesthetic values of the work, it is no need to wonder on its linguistic richness and classic style, if we consider that the author was the professor of Old and Middle English

60 Cf. Ward, I.: Law and Literature: Possibilities and Perspectives. Cambridge, 1995, 90-118.

${ }^{61}$ Eco, U.: Postscript to The Name of the Rose (translated by Weaver, W.). San Diego-New York-London, 1983.

62 Tolkien himself called his writing "mythopoesis" in a discussion in the early 1930s. Cf. Carpenter, H.: The Inklings: C.S. Lewis, J.R.R. Tolkien, Charles Williams, and their Friends. London, 1978 . 
in Oxford, who invented new languages in his freetime. ${ }^{63}$ This linguistic richness is especially important for lawyers-to-be who will be "professional translators", since the mediation between the different subcultures of their professional groups-judges, attorneys, policemen-, and of the different social groups belongs to the very matter of their profession, they have to work as translators in the communication among these various groups. ${ }^{64}$ This means that they ought to learn to speak to everybody on her own language.

The evaluation of the message of the work has divided the literary critics since its publication. Influential authors-e.g. W.H. Auden, C.S. Lewis-have enthusiastically praised it, while others of not less specific density-e.g. E. Wilson, E. Muir and P. Toynbee-, have heavily criticised it. The present author, as an uninitiated, would not incline to take part in this discussion, only brings out his opinion.

In my opinion, The Lord of the Ring's primary value is that it re-tells the traditional mythological matter, expressing a heroic value-system, in a modern fashion inspired by the Christian values ${ }^{65}$-such as compassion, forgiveness, and generosity-adding to these the idea of undertaking responsibility for the future of our world and for the preservation of all the nature's values. I believe that these ideas will have an actual importance in the long run-maybe even for the lawyers-to-be.

${ }^{63}$ On Tolkien's biography see Dougham, D.: "Who was Tolkien?" [http://tolkiensociety.org/ tolkien/biography.html]. White, M.: Tolkien: A Biography. London, 2002. 1990.

${ }^{64}$ Cf. White, J. B.: Justice as Translation. An Essay in Cultural and Legal Criticism. Chicago,

65 About the role played the Catholic faith in Tolkien's life see White: Tolkien, 22-31. 